\title{
1860年代のロシア極東における植民都市の初期市街地計画 EARLY CITY PLAN OF COLONIAL CITIES IN 1860'S OF RUSSIAN FAR EAST
}

\author{
佐 藤 洋一* \\ Yoichi SATO
}

\begin{abstract}
The basic factor of urban formation of colonial cities in Russian Far East was clarified by the comparison among the early city plans of Bragoveshchensk, Khabarovsk and Vladivostok, which were commonly constructed almost the same time, 1860's. By comparing extent of planning area, land condition, street pattern, dimension of street width and block, form and dimension of the land lot and the facilities, besides considering geopolitical background in those days, the completed form of the city was not described in the initial plans and the principal objects to plan were 4 points of the configuration of fundamental facilities such as; 1)extent of urban area, 2)form and dimension of land lots for sale, 3)location of graveyard and church, 4)location of wharf, market and open space for trading. Following this, it was shown that the initial plans could be understood as measures of securing military base and settlement in the frontier region.
\end{abstract}

Keywords : Russian Far East, colonial city, urban history, central district, street pattern ロシア極東、植民都市、都市形成史、中心市街地、街路パターン

\section{1.はじめに}

本稿は 19 世紀後半に、ロシア極東地域に建設された帝政ロシア による 3 つの植民都市、ブラゴベシチェンスク、ハバロスク、ウ ラジオストクにおける 1860 年前後の初期市街地計画の特質を検討 するものである。

\section{1-1. 帝政ロシアの東進 1 と極東地域}

16 世紀より、主にコサック隊を前面に水路を使いつつシベリア を陸続きに東進した帝政ロシアの拠点形成は、領土が確定していな いが、先住民の生活空間であった地に侵入し進められた（図 1）2。 アムール川（中国名 : 黒竜江）流域への南下は、1640年代以降 に始まり、アムール川上流のシルカ川に面したネルチンスク（1659 年創設)、アムールルに面したアルバジン（1651 年創設）という拠 点が形成されたが、モンコル人、及び彼らを従属していた中国の激 しい抵抗を受けた。1682 年に中国軍がアムール川右岸の愛琿に根 拋地を建設した後は、流域での軍事活動が活発化する。結局 1689 年のネルチンスク条約により、ロシアはアムール流域から撤退し、 流域北側のスタノボイ山脈の分水领が、中露国境と定められた。

その後、約 150 年にわたり、アムール流域の中露関係は平穏な時 期が続くが、1847 年にムラヴィヨフ（N.N.Muraviev）が東シベリ ア総督（general-guvernator Vostochnoi Sibiri）に就任すると、 アヘン戦争によるイギリスの中国進出に対抗すべく、アムール流域 への再進出に乗り出す。1849 年、彼の部下であるネヴェリスコイ が、カムチャツカ半島ペトロパブロフスクを根拋地にし、アムール
河口調査を開始した。翌年、河口付近にニコラエフスク（現ニコラ エフスク・ナ・アムーレ) を建設、その後もこの流域でロシア人占 領の既成事実が積み重ねられ、ロシア皇帝から清国との一切の交渉 権を一任されていたムラヴィヨフは、1858 年に清国政府との愛琿 条約の調印にこぎつけ、アムール川以北の領土はロシアへ割譲され た。つづく 1860 年の北京条約では、ウスリー川と日本海との間に 挟まれた区域（沿海地方）をロシアへ併合することが承認された。

ブラゴベシチェンスク、ハバロフスクは愛琿条約を根拋として、 ウラジオストクは北京条約を根拠として 19 世紀後半から建設が進 められた都市である。ほぼ同時期に形成が始まったこれら 3 都市 は、ウラジオストク (Vladivostok) の名称が端的に意味するよう に、ヨーロッパロシアから見たまさに東の果ての地域に存在してお り、また中露間の国際条約によって清国から割譲を受けた領域内に あることも含め、シベリア地域の諸都市とは出自の経緯を異にして いる。シベリア・極東の帝政ロシア植民都市の系譜においては、末 期に位置するものとして捉えることができる。

\section{1-2. 本稿の目的}

本研究はシベリア・極東における帝政ロシア植民都市形成の系譜 を明らかにすることを目的としており、1860 年代において計画が なされた帝政ロシア末期植民都市の形成上の特質を初期市街地計画 の比較を通して論じるものである。

また、本論で対象とする 3 都市は、この市街地計画以後、ロシア 国内での移民政策や周辺国からの流入者の増加に伴い、都市建設が

\footnotetext{
$*$ 早稲田大学芸術学校 講師・博士 (工学)
}

Lecturer, Art and Architecture School, Waseda Univ., Dr. Eng. 
進行し、19 世紀末から 1910 年代までに現在の中心市街地の都市空 間形態の原型が形作られている。本稿は、こうしたく建設期>にお ける都市空間形成の前提となった市街地計画上の計画内容を明らか にしょうとするもので、ロシア極東の都市に䦎する基礎的な研究と なることを望むものである。

\section{1-3.内外の研究状況}

(1)日本国内／国内においてシベリア・極東の帝政ロシアによる都市 形成を扱った研究は極めて少ない。19 世紀末の帝政ロシアによる 植民都市であるハルピン、ダリニー（大連）に関する歴史について は、越沢の研究と、中国東北地方の都市と建築を紹介した西澤の著 墨がある。解放前までの両都市の都市形成を、主に計画的な側面か ら論じる越沢の二つの研究文4-5) では、ハルピンに関してはその前 半部分で、また大連に関しては最初の部分で帝政ロシアによる計画 が扱われている。西澤の研究文6-7)においても、冒頭において帝政 ロシアの極東政策の経緯が紹介されているが、これらの成果の中で は、ロシア極東諸都市に関しては断片的にふれられているにすぎな い。またウラジオストクの都市形成を対象としたものとしては、原 及び筆者らの研究があるのみである。原の研究文8) は、帝政期のウ ラジオストクの都市史を多角的に論じているが、空間的な事象には 関心が向けられていない。一方等者らによる研究文9-10) は、ウラジ オストク中心市街地における 2 つの地区の空間形成を事例的に論じ たものであり、初期の計画は十分に㭘討されていない。 (2)ロシア/一方ロシアにおける研究成果のうち、16 世紀後半〜 20 世紀初頭のシベリア。極東の諸都市の形成を対象とした近年の研究 では、その多くが単一都市を対象としたモノグラフである。その内 容は、都市骨格形成の問題から建築物（初期の木造要塞から教会や 民間の都市建築まで）まで多岐にわたっている3)。

このうち特に注目すべきはProskuriakova、Kradin、Obertas による研究である。Proskuriakova の研究义11-12) では、西シベリア から東シベリアにかけての諸都市の都市骨格形成の特徽を明らかに しているが、極東地域に関してはふれられていない。またKradin文 13-14)、Obertas 文15-17) の成果にはそれぞれハバロフスク、ウラジオ ストクの都市・建築に閵するモノグラフが含まれるが、両者とも全

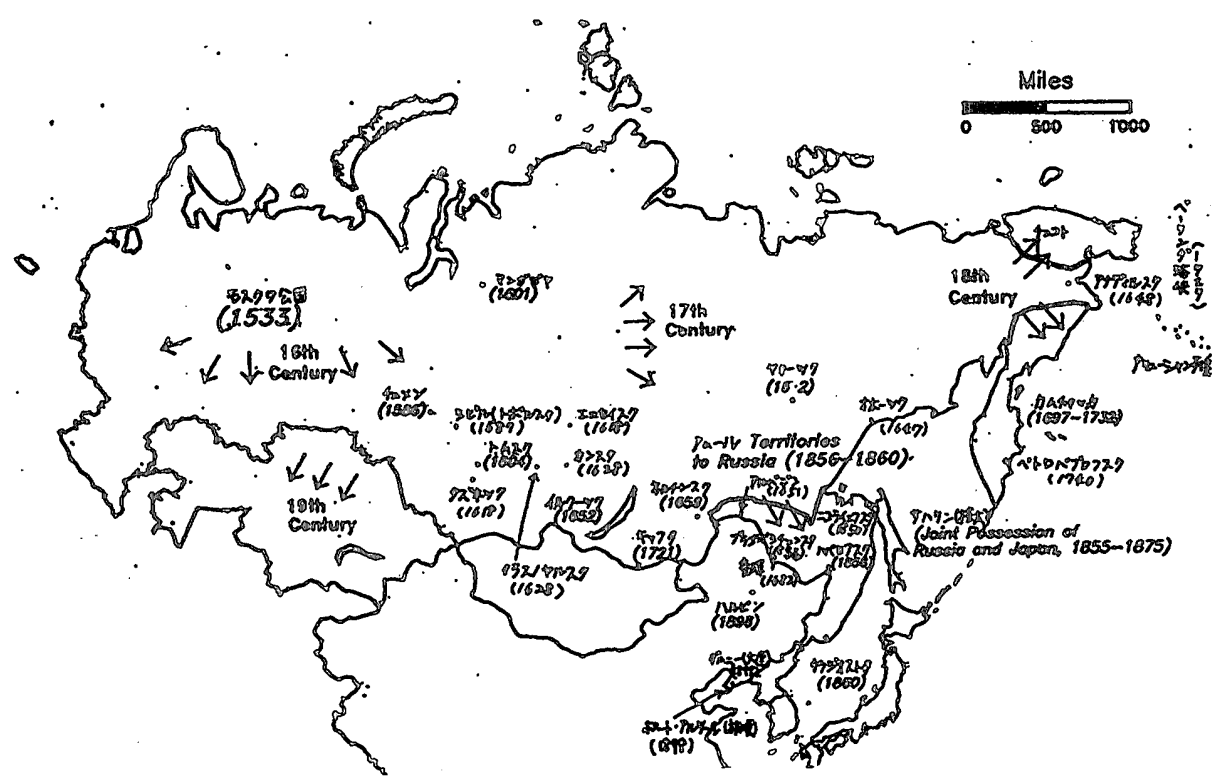

图 1 帝政ロシアの東進過程と主要都市の創設年 (Kotkin,.Wolff(ed)“Rediscovering Russia in Asia” 1995 に加筆)
体として建築物に関心が向けられ、初期の市街地計画にふれてはい るものの、計画の内容に対する踏み込んだ検討は見られない。

\section{1-4. 研究の方流}

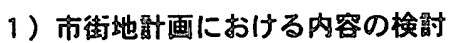

(1)検討内容／本稿では、3都市の初期の市街地計画図、市街地図お よび文献史料 4) などから市街地計画における内容を検討し、その比 較から都市間の共通点、相違点を明らかにする。具体的な検討内容 は、(1)計画節囲と土地条件、(2)街路パターン、(3)街路及び街区規 格、(4)土地ロットの分割方法と寸法、(5)施設計画である。 (2)初期の市街地計画図、市街地図/計画内容の直接の検討材料とな るのは表 1 に揭げた地図 I 〜 II である。各図の表記内容は同一でな く、原地形との関連や街路パターン、大規模な都市施設に䦥する情 報は得られるが、街路・街区規格を推定する際には、縮尺の精度が 粗い。本諭では以上の図面を初期市街地計画を検討する主な対象と するが、寸法の推定及びロット割りについては、その後 $1900 \sim 10$ 年代発行の市街地図（地図IV〜V) ${ }^{5}$ )を補足的に使用する。

\section{2) 植民都市としての特留}

対象 3 都市は、シベリア・極東の帝政ロシア植民都市の系譜の中 では、末期に位置するものとして捉えることができる。本論での空 間的条件の検討に基づき、3都市の植民都市としての初期計画上の 特質を指摘したい。

\section{2. 文献に見られる初期市街地毁画前後の状況}

市街地図の分析に先立って、文献による情報をもとに、各都市の 市街地計画までの状況を整理しておく。

\section{2-1. 畔画前までの状況}

1) ブラゴベシチェンスク

(1)抛点の選定。設置／1856 年にコサック隊がウストーゼイスク (Ust'-Zeisk) という名の根抛地を設営する以前は、中国名・海蘭 泡という名の集落が付近にあったとされている。コサック隊の根拠 地は、その後市街となる場所よりも 4〜 5ウェルスト（1ウェルス タ=1.067km）下流に造られていた。1858 年にブラゴベシチェンス クと命名され、アムール川とゼ一ヤ川の合流地点を中心に海軍の手 によって新たな拋点が造られた。 (2)市街地計画策定前の建物・人口／最も 初期の建物は、軍務知事の住居、軍政府 の建物、官燎と軍の上官用の住居、コ サック隊の本部であり、建設資材などの 運搬はコサック兵の義務とされた。1859 年の末には、24の官有建物と 5 つの民間 の建物があったが、その 1 年後には、そ れぞれ 59 と 24 と增加している。1 858 年の人口は約 1,500 人で、 65 年には 3,000 人を数えている。最初の市街地計 画が立案される 1862 年にはすでに市街 地構成の基本形と 5 本の街路（ボリショ イ、ナベレージュナヤ、ゼイスカヤ、ア ムールスカヤ、レローチュナヤの各通り) が姿を現していた。

2) ハバロフスク 
(1)拋点の選定・設置／1858 年にアムール川に対してほほ直角に迫. る3つの高台をハバロフカ (Khabarovka) ${ }^{6)}$ と命名し、抱点の建 設が始まる。この場所を選んだのは、前年にニコラエフスクを出発 し、アムール川の遠征を行っていた海軍大尉ティアチェンコ (Ia.V.D'iachenko) であったとされる。

(2)市街地計画策定前の建物・人口／1859 年の記録では、河から望 むことができる高台の上に、棚で囲まれた住居の他、国境警備隊の 兵舎、礼拝堂、アムール会社の建物などがあった。兵士や移民のた めに最初に建設された建物の多くは、粘土造の仮設建築であった が、徐々に木造の建物に置き換わっていった。設営から 5 年後 （1863 年）には市街地計画が立てられ、この時点で 167 の建物が 建っており、それらは全て木造であった。1864 年の人口は 2,100 人であった。

3) ウラジオストク

(1)抸点の選定・設置/ウラジオストクは、ムラヴィヨフが1859 年 に出した指示に基づき、南に位置していたポシェット湾と同時に哨 所が設置されたという経緯をもつ。1860 年に哨所の設置が開始さ れたころ、湾の入江には中国人出稼ぎ漁民の小屋が数戸あり、海参 蔵（Khai-shen'-vei 中国名：ハイサンウェイ）と呼ばれていた。 (2)市街地計画策定前の建物・人口/その後、市街地計画が立てられ る 1868 年までの間に、教会を始め、兵舎、将校用の住居、機械工 場、倉庫、食糧貯蔵庫などが建てられた。記録によれば、1868 年 には、官有建物 32、私有建物 35、それに 20 の中国人の房子 (fanza : ファンザ) 7) があった。1 1868 年の人口は 510 人で、軍務 関係者とその家族が 348 人、民間人が 89 人、移民及び退役兵士と その家族が 37 人、それに 36 人の中国人であった。また 1862 年に は民間人であるセミョーノフ (Y.L.Semenov) は初めて住居用の 20 サージェン四方の土地と草刈り場の分譲を受けた ${ }^{8)}$ 。

\section{2-2. 軍政組裁およひ的的側面}

市街地計画策定がなされた 1860 年代においては、3 都市とも軍 政下にあった。ブコざシチェンスクにはアムール州（Amurskaia Oblast' : 1858 年に創設) の行政の中心が置かれ、その軍務知事の
エフスクに本拠のあった沿海州 (Primorskaia oblast') 軍務知事の 管轄下にあった。アムール州と沿海州はともにイルクーツクを本拋 とする東シベリア総督（1822 年に創設）の管理下におかれていた。 のち 1884 年に東シベリア総督の管轄下からアムール地方総督が新 たに創設されて改組し、その本拋地はハバロフスクにおかれた。す なわち、3 都市の計画当初の行政組織は、東シベリア総督の軍政の 管理下におかれ、その下に各州の軍務知事がいて、各都市には要塞 司令官がいるという構成となっていた。

沿海州の管轄下におかれていたハバロフスク、ウラジオストクの 最初の市街地計画は、ともに、ロシア海軍の測量技師で、1862 年 に沿海州の測量士に任命されたルビアンスキー（Mikhail Riubenskii) によって立案されたとされる ${ }^{9}$ 。ブラゴベシチェンス クの計画立案者は現時点では不明である。

\section{2-3. 計画プロセスをめぐる記述}

ハバロフスクの計画策定に際しては、ルビアンスキーが 1863 年 春に現地に到着し、土地の測量を行い、計画図の作成を行ってい る。後に検討するとおり、この計画図には街路敖設のための森林の 伐開線の表示のほか、街区形態、街区内のロット割りなどが示され ている。そして翌年にはイルクーツクの東シベリア総督コルサコフ (P.K.Korsakov : ムラウィョうの後任で、1861 年に就任) にあて て、計画図を送付し、検討及び承認を求めている ${ }^{10)}$ 。

ウラジオストクの市街地計画にあたっては、計画策定に先立つ 1864 年 7 月に沿海州軍務知事が市街地建設の場所の選定を州の測 量技師に依頼したが、実施されなかった ${ }^{11)} 。$ 翌年 7 月にコルサコフ から市街地計画基本方針が出されている。そこには、土地の分培を 前提とすること、街路幅員、街区の形状、ロット割りに際しての原 則、1ロットのサイズなどが示されている12)。しかしながら、これ もすくに実行に移されたわけではなく、1866 年 2 月になってルビ アンスキーが到着し、翌年計画が策定され、12月にハバロフスク 同様に東シベリア総督に対し、沿海州軍務知事が文書にて説明を 行っている13)。この計画は、上述した沿海州軍務知事による基本方 針に則つたものとされる ${ }^{14)}$ 。

管轄するところとなった。ハバロフスクとウラジオストクはニコラ

表 13 都市の初期市街地計画図と表記

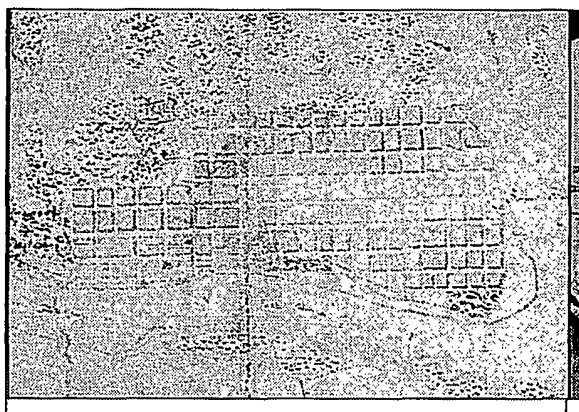

(1)名称・作成年 (所藏): "Plan"Zorogskoi Zemli" 1869 (フラゴベシチェンスク市役所所蔵)

(2)原図の樎尺 : 約 42,000 分の 1 (図中 1 インチ $=1$

ウェルスタ)

(3)図中の表記内容 : 市街地計画の範囲と街路骨格パ ターン。これらの表記の他、後背の河川・森林などの 自然地形が等高線を含めて広い籍囲で描かれている。 また测量地点とその番昘もブロットされている。

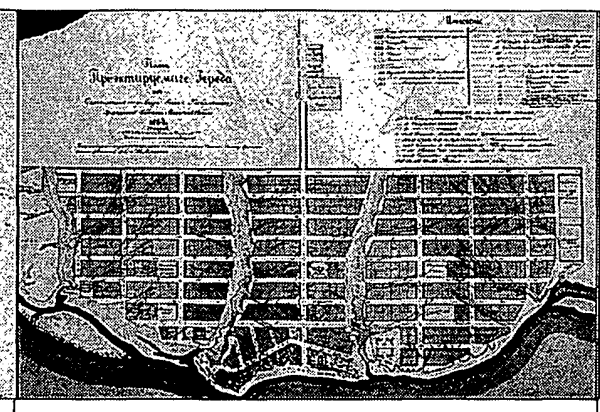

(1)名称・作成年（所藏）: "Plan"Proektiruemogo Goroda " 1864 (Khabarovsk Regional Lore Museum 所蒇)

(2)原図の唃尺: 的 3,500 分の 1

(3)図中の表記内容: 市街地計画の籍囲と街路骨格パター ン。街区のロット分割線や、各種施設の名称と番号もプ ロットされている。また、各街区には通し番号が付され ている。市街地計画の箸囲のみ描かれており、後背地の 情報は表記されていない。

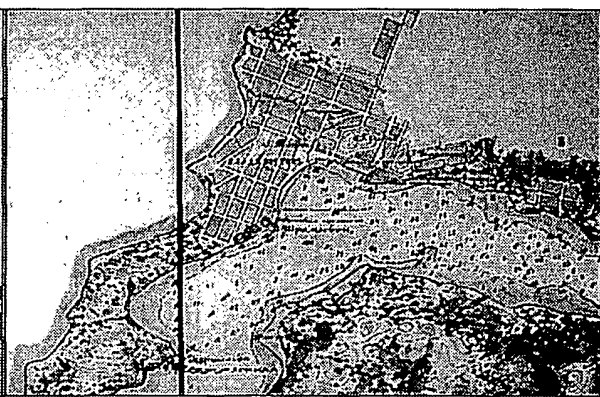

(1)名称·作成年 (所藏):“Plan" Proektironainogo Goroda Vladivostok" Primorskol Oblasti Vostoch Sibiri" 1865 (Museum of Vladivostok Fortress 所葴) (2)原図の縮尺: 約 22,000 分の 1 (推定) (3)図中の表記内容 : 市街地計画の範囲と街路骨格パター ン。海の水面部分には水深表示があり、また後背の河川・ 森林などの自然地形が等高楾を含めて描かれている。市 街地北側が広い籍囲にわたり不自然に白く染りつぶされ ているが、これは軍事機密の観点からと考えられ、後年 に染りつぶされたものと思われる。 


\section{2-Q. ॠと的}

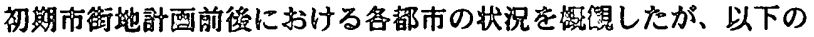
上うな共通点があげられる。すなわら(1)初期計西に先立って、海諠

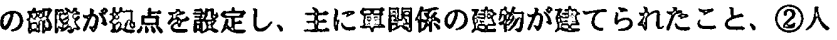

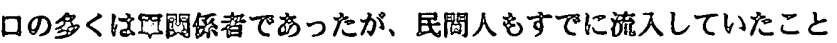

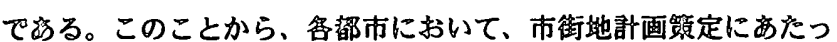
ては曆び民問人がすでに利用を閶始していた既存の土站区四との

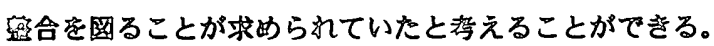

一方、訫面当封の各都市をとりまく政の将況は異なっていた。

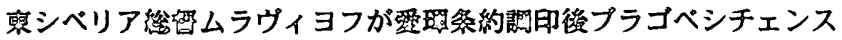

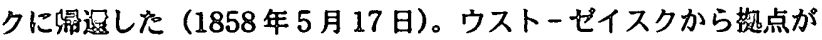
移され沉跱期（1858年 7 月 5 日）は、彼がブラゴベシチェンスク

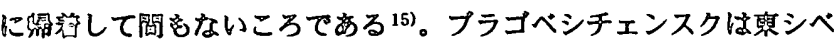

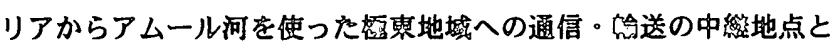
して、あるいは中国との問の封外的な敬点と見なされていた。祭約

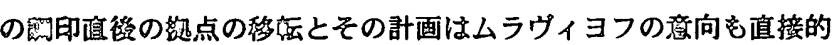
に反跑されていたものと衫えられる。

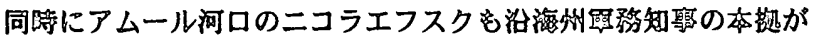

存在し、ロシア砮临のもう一つのセンターとして位四づけられてい

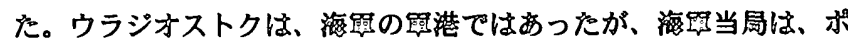

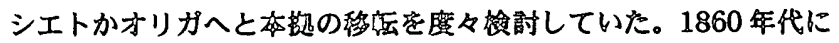

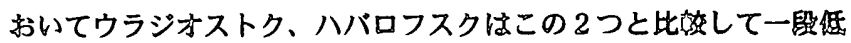
い地位にあった ${ }^{16)}$ 。

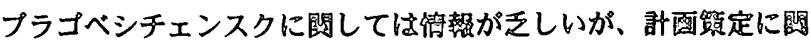

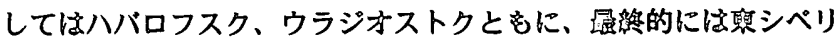

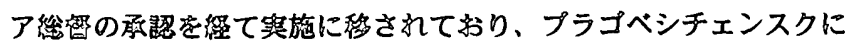
閣しても同様の手续きが取られたことが推察される。きた、計西方 針に閶してもウラジオストク以外の都市では不明であるか゚、後に蛒 討するとおり、ウラジオストクで示された祭件は绿ハパロフスク の計图にも当てはまるものであり、同一人物による計西であること

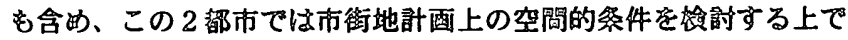
額似点が多い。

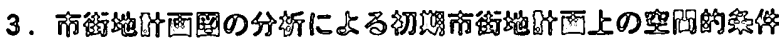

前出の地图 I 〜 Vに基づいて、以下で考察する初期市得地矿面上 の空間的条件を抽出し、下图 2〜4を作成した。それぞれの圈の表
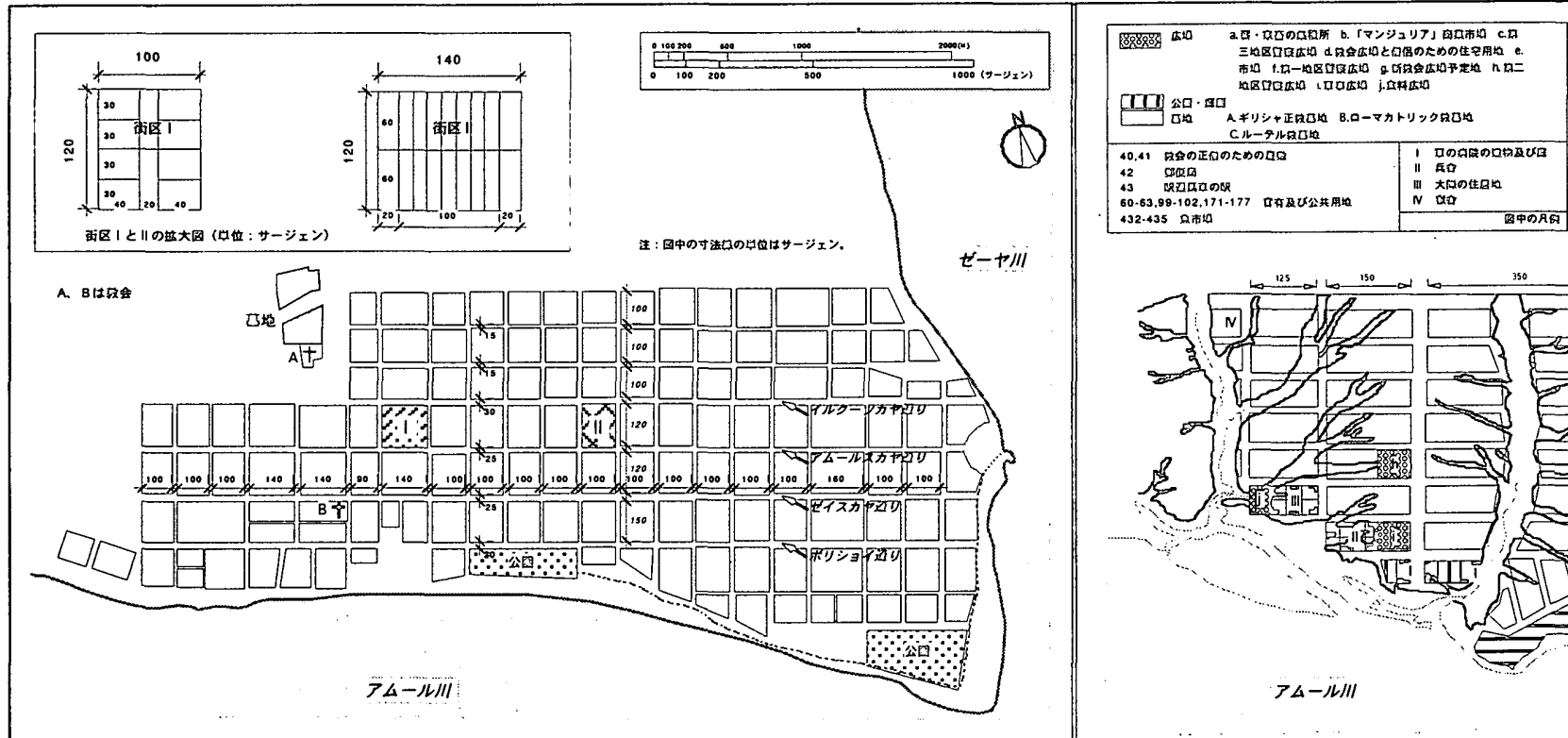

图 2 ブラゴベシチェンスク初期計画推定图

曰ブラゴペシチェンスタ（圈 2)

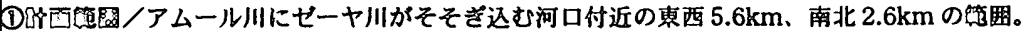

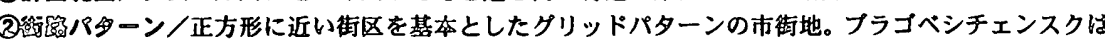

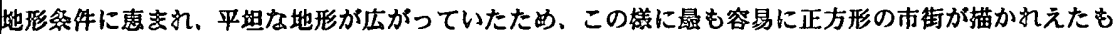
のと斿えられる。アムール川治岸の崖地で、広埸、公園などが酉され、市街の中心を治岸部に計画し 儌が同える。

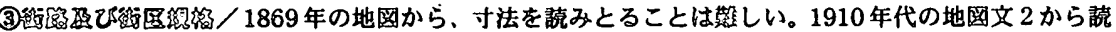

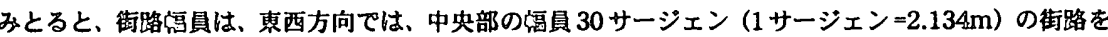
中心に南方向へ 25 サージェンの街路 2 本、そしてアムール川と接する街路は20サージェンである。市

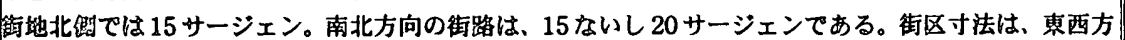
向ではほぼ100サージェン (=213.6m) を基調としており、部分的に $160 、 140 、 90$ のものが見られる。 䒠北方向は南僛では 120 サージェン、北側では 100 サージェンである。

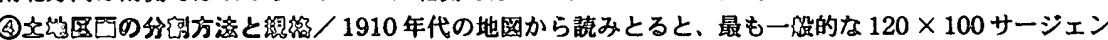

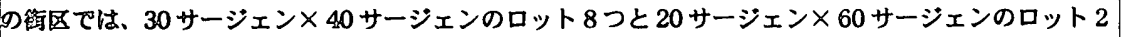

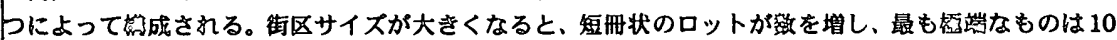
×60サージェンというものも存在する。

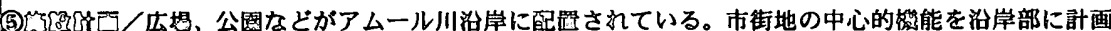
していた㖩が同える。2 カ所に教会の表記が見られる。 
記内容に関する分析は、図の下に示した。(1)計画籁囲と土地条件、 (2)街路パターン、(3)街路及び街区規格、(4)土地区画の分割方法と規 格、(5)施設計画、の諸点に関する表記を検討する。

\section{4. 比校}

\section{4-1. 共通点}

(1)グリッドパターンによる空間分割システム/共通に見られる最も

顕著な点は、街路構成がグリッドパターンによっていることであ る。これは、土地区画の規格的な分割を可能にするという镍点から なされていたものと判断でるるこれは各国の植民都市に共通の計 画手法であり、18 世紀のシベリア都市における市街地計画に、同 様の手法が見られる ${ }^{17) 。 ~}$

先に述べた東シベリア総督コルサコフによるウラジオストクの市 街地計画に対する基本方針は、土地区画の分割についても亩及して

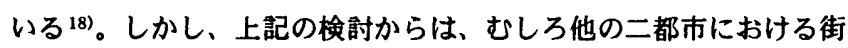
区一土地区画の形状と寸法がより規格的であることが明らかであ り、こうした分割方法は、3 都市共通のものであることがわかる。 (2)埠頭とオープンスペース/地図 I 〜 III の表記から判断すれば、埠
頭付近にオープンスペースを確保している点は 3 都市共通に見られ る点である。最初の市街地計画において、施設計画に対する明確な 考え方の有無を現時点で結論付けられないが、埠頭付近のオープン スペースには造形デザインの面で、当初から象勧的な意味合いを付 与されていたとは考えにくい。その後の、特に鉄道開通 ${ }^{19)}$ までの 間における、唯一の人や物資の流入口であり、ここを中心に市场や 商店などが集積し、都市化の核となったことが重要な論点である。 (3)地形の整備/原地形が平坦なブラコベシチェンスクのみならず、 起伏が激しいハバロフスク、ウラジオストクにおいても、グリッド パターンを具現化するにあたっては、大規模な土地の造成は行われ ず、最低限度の地形の整備で済ませていたことが判る。

\section{4-2. 特有の要表}

(1)幅員からみた街路の等級/格子を構成する街路の幅員は、ブラコ ベシチェンスクでは、25サージェンを筆頭として、20、15サー ジェンである。ハバロフスクでは、文献に書かれた街路幅員に関す る東シベリア総督コルサコフの原則通り ${ }^{20) 、 25 、 20 て ゙ あ り 、 ウ ラ ~}$ ジオストクでは原則とは異なり、それぞれ、15、10 となる。

最大幅員をもつ街路は、ブラコベシチェンスクでは市街地中央部
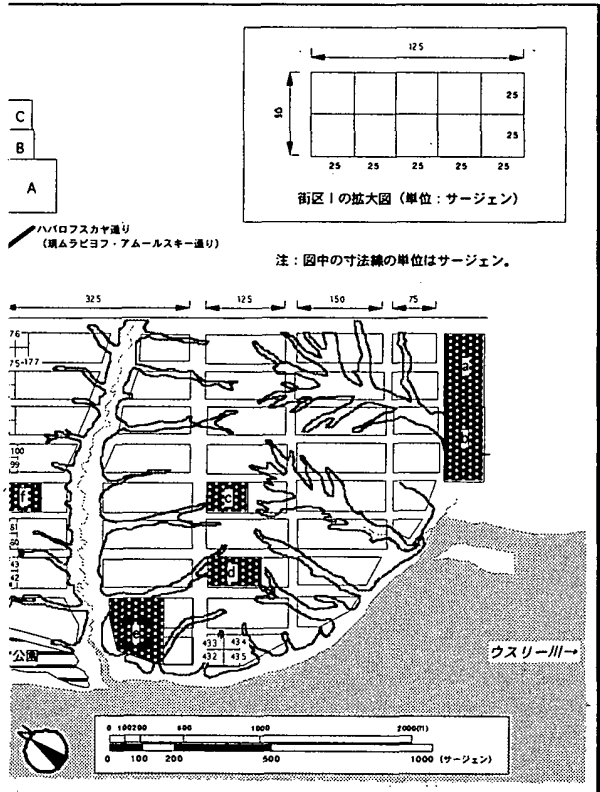

図3 ハバロフスク初期計画推定図

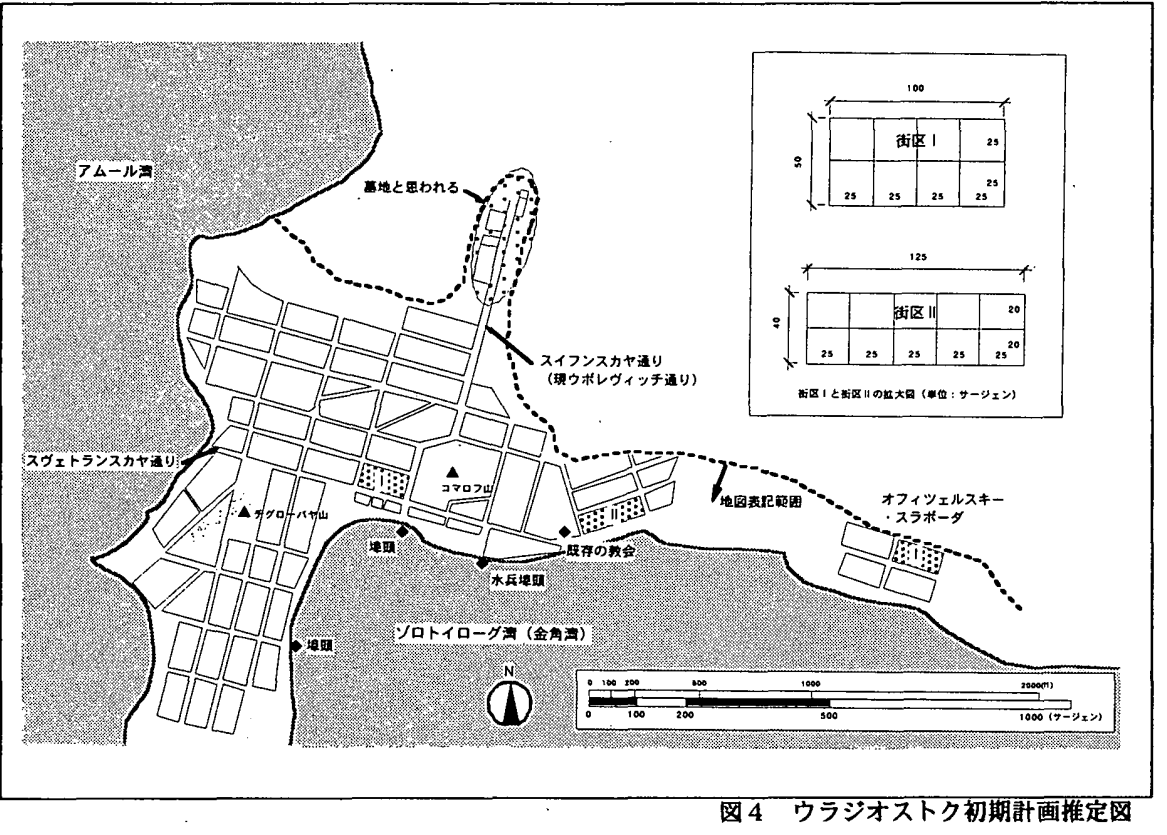

ロウラジオストク (図 4)

つの谷にまたがる $3.4 \mathrm{~km} \times 1.3 \mathrm{~km}$ の範囲。 ンを基調としている。格子は川から北東方向に走る 3 川によって、横断する街路が連䌇しておらず、格子が完 形に变化が現れ、格子が朋れているとともに、公園など ていたことを伺わせ、尾根道は当初から主要街路とし

とが可能である。街路蝠員は、3本の尾根道と市街地北 ン。主要道には、両侧に植載の表記がある。街区寸法は、 定し、長扨は $125 、 150 、 175$ サージェンのいずれかて

が入り、長辺を $5 \sim 7$ 等分し、計 $8 \sim 12$ のロットで 1 なまてに一定しており、これがーつのモジュールとな る。またこの時点で、すてに街区内のロット割が書き込 前提とされていたことが伺われる。

いる。また市街地西部には軍関係の施設、東部には市堨

(1) H画籍团/シコタ半岛付け根を中心とした南北 $2.4 \mathrm{~km}$ 、東西 $2.1 \mathrm{~km}$ の範囲

(街路パターン/グリッドパターンを基媩としているが、中央の低地部分において 2 カ所斜行する短い街 路が見られ、この部分での得区形状が異なる。海岸線に東西に沿うスウェトランスカヤ通りの地形は、比

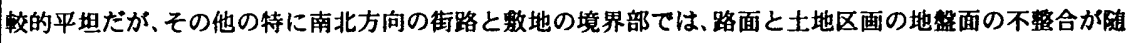
所で見られる。部分的に盛り土・切り土をして対応したとの記録が残されている。

(街路及ひ街区寸法/1910年の地図Vより寸法を割り出すと、街路幅員はスイフンスカヤ通り（現ウボ レビッチ通り）が約 15 サージェン（約 $32.0 \mathrm{~m} 。 1$ サージェン=2.136m)、中央部を斜行するカソイペレ ウーロク、マルケロフスキーペレウーロクが約 8サージェンである以外は、どれもほほ10サージェン(約 $21.4 \mathrm{~m})$ 。街区は中央部の 3 街区がややスクエアな形状だが、その他は南北約 50 サージェンでほほ同一。 東西方向は南部の 6 つの街区ではそれぞれ寸法が西㑡より112、112、96サージェン、北部ては西側より 112、112、152〜160 サージェンであり、街区により寸法にばらつきがある。

(4)土地区画の分割方法と规格/方形街区は短边に背割り線が入り、長辺を $4 \sim 6$ 等分し、計 $8 \sim 12$ の ロットで 1 街区が構成される。㪙地规模の標帮は市街で 25 サージェンとの記述があるが、1910年の地 図により算出すると、24サージェン×24サージェンという数地寸法が算出された街区が一つある以外は、 いずれも 24 サージェン× $22 \sim 23$ サージェンであり、ほぼ同一である。

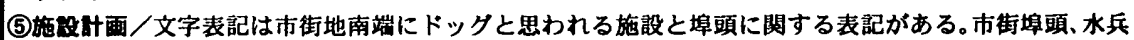
暤頭、中国暏頭などの名称が表示されている。旧市埸付近は、オープンスペースとして提えられていたこ とが影みとれる。 
を東西に走る街路であり、ハバロフスクではアムール川へ垂直に対 する 3 つの台地の尾根部分を走る 3 本の街路が等しく 25 サージェ ンであるが、ウラジオストクの場合、市街埠頭から市街地を南北に 横切り、墓地へと通じるスイフンスカヤ通りのみが 15 サージェン である。ハハロフスクにおけるこの 3 本の街路は、谷によって分け られる 3 つの地区の主要街路として計画されていたことがわかる。 ウラジオストクでは、最高幅員が 15 サージェンであり、街路幅員 は各都市でかなり異なっている。その原因としては、ウラジオスト クの急惨な地形による平坦地の不足、市街地緑辺部における要塞の 存在を指摘することができる。他の 2 都市と比べれば、土地の制約 や街路幅員など、その後の都市空間形成において、市街地が比皎的 高密となるような条件がこの時点で準備されていた面がある。

この他、格子で区切られる街区を更に細分割している街路が見ら れる。これらはブラゴベシチェンスク、ウラジオストクではペレ ウーロク (pereulok) と呼ばれる。その幅員は、ブラコベシチェン スクでは10サージェン、ウラジオストクは8サージェンである。 ハバロフスクではこのような街路は見られない。 (2)格子の朝線及び街区形状/ブラゴペシチェンスクは、沿岸部分で 格子が変形することを除けば、ほぼ直交の格子が隙間なく広がって いる。ハバロスクでは、2つの谷によって格子が寸断されている 部分があるが、直交する座標軸自体は、計画区域全体に行き渡って いる。特に中央の台地の尾根道は、沿道の公共的な土地利用まで計 画されていることから、ここが最も主要な街路として捉えられてい たと考えることができる。ウラジオストクではグリッドパターンを 基調としているが、他の 2 都市がより広い筑囲で格子を払張してい るのに対して、地形との関係により、随所で格子が崩されている。 しかしあくまでグリッドパターンを教衍しており、ここからも当初 計画では土地区画の分割に重点がおかれたことが理解できる。

プラゴベシチェンスクの街区形状はやや正方形に近く、他の 2 都 市とは明らかに異なる。なぜこのような違いがあるのかに関して は、証抛となる直接的な資料はないが、次節において、いくつかの 推論を立ててみることにする。

(3)土地区画の分割方法及び寸法/ハバロフスクとウラジオストクの 市街地計画においては、基本的に同一のスケール及び形状をもった 土地区画を分淁することが念頭におかれていたといえる。ウラジオ ストク市街地での格子が崩れている一部の場所を除けば、両都市と も 1 ロットが 25 サージェン四方という原則があったことがわかる。 面䅡にすると 625 平方サージェンであるが、ブラゴベシチェンスク のロット面積は、大きいロットで 1200 平方サージェン、小さいと ころでも 600 平方サージェンであり、他の 2 都市より大きいものと なっている。帝政期における土地分誶のあり方は、一人の（あるい は 1 世帯の) 所有できる土地面積が定められた帝政時代の法律の存 在によって規定されていたともいわれるが21)、現時点においては定 かでない。

\section{5. 房察}

\section{5-1. 红地区画之面筑}

この 3 都市の中心市街地は、初期市街地計画以後、ロシア国内で の移民政策や周辺国からの流入者の増加に伴って建物の更新之増加 が進み、1910 年代までに現在の都市空間形態の基盤が成立してい
る。上で検討した土地区画は、部分的に細分化、集約化が見られる が、建物更新の際の基淮となる単位、すなわち一敭地として機能し ていた。

のちに社会主善体制下において土地が公有化されることにより、 土地区画のあり方を支えている制度的基盤と社会的意味づけが大き く変わる。すなわち土地の所有境界としての土地区画は意味をなく し、建缷接都市計画においては、むしろ物理的な境界である街 区が基準単位、すなわち一敭地として捉えられるケースが䫓著に見 られるようになった。現在の形態はソビエト期における改変を受け ているが、帝政時代に建設された建築物はこの敷地区画の存在を前 提として存在しており、また 90 年代以降更に土地所有制度が変容 していることも考えあわせると、市街地の建築物なども含めた空間 形態の変容を通時的に捉える場合には、土地区画を基準とする必要 があることが分かる。

次に、敨地面穞に関してふれておく。ハバロフスク、ウラジオス トクの市街地計画においては、1 ロットが 25 サージェン四方、す なわち 625 平方サージェンが基本であり、ブラコベシチェンスクの 場合は、全体的にそれを上回る面積をもっていた。

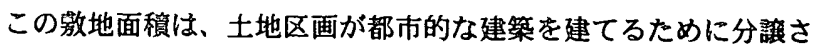
れたものではなく、市街化初期に見られたような「農村」的な市街 地の形成のために分绫されたものであることを示していると考えら れる ${ }^{22) 。}$

いいかえれば、3 都市の初期市街地計画においては、将来出現す るであろう都市的な諸活動の場を形成する基本単位として敬地規模 が決められていたわけではなく、当時のシベリア以東における都市 移民の居住形態を前提として定められたものだと推論される。区画 内での土地利用の典型的なものは、写真 $1 \sim 3$ にもあるように、敷 地境界を不製の㯰で囲い、木造の母屋と家畜小屋、付属屋と、菜園 によって棈成される。土地区画の面積は、こうした土地利用を確保 するものであったと考えられよう。

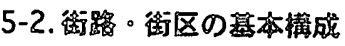

街路・街区の基本構成自体が、都市によってなぜ違うものになっ たのか、という要因を考えてみたい。

3都市で原則的に用いられたグリッドパターンは、土地を調查し たり、分割したりするのには便利であり、多くの植民都市で採用さ れてきた手法である ${ }^{23)}$

ブラゴベシチェンスクの街路構成は、極東での帝政ロシアの進出 の最初の足がかりとして 1850 年から建設が始められたアムール河 ロのニコラエフスク（現 : ニコラエフスク・ナ・アムーレ）の搆成 と類似している。地形条件から見た川と市街地の関保、正方形に近 い街区による權成は酷似している。この両都市にはそれぞれ建設に 前後してムラピヨフが訪れており、市街地計画にあたっても彼の考 えが直接的に反映された可能性も考え得る ${ }^{24)}$ 。

一方でハバロフスクとウラジオストクの市街地計画は、コルサコ フによる市街地計画の方針が出された後の計画であり、同じ測星技 師ルピアンスキーによって市街地計画が立案された。街路。街区桡 成の差異をもたらした要因として考えられるのは、計画に関わった 人的な条件、及び当重者の有していた職能と知識である。これに関 連して、若千の知見を補足しておく。

当時の軍の測量職には、「トポグラフ (Topograf)」と「ゼムレ 


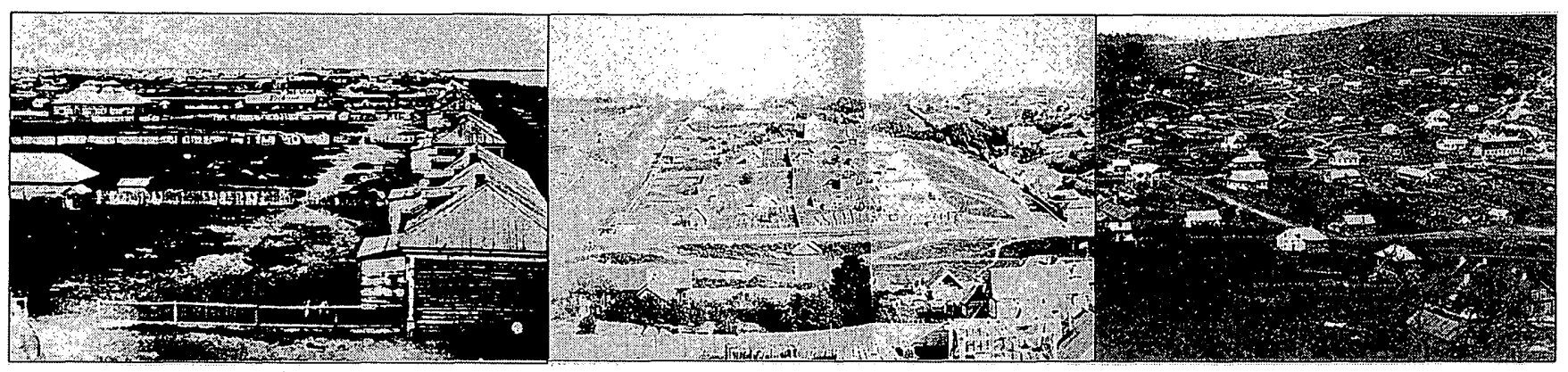

左から、写真 $1: 1879$ 年のブラゴペシチェンスク（北海道大学付属図書館北方資料室所藏）、写真 $2: 1880$ 年代のハバロフスク市街地（出典 “Khabarovskii Krai" 1996)、写真 3 :ウラジオストク中心市街地 1870 年代 (出典 “Vladivostok" konets XDX - nachalo XX veka” 1992)

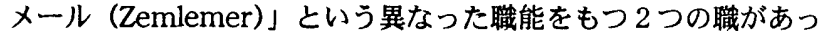

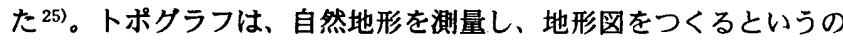
がその主な雅務内容であり、一方ゼムレメールはそうした測量成果 をもとに、土地の分謞およびその価格などを鑑定し、価值を証明す るという不動産鑑定的な硪務内容を含んでいた。市街地計画の立案 は、具体的な場面では、この両者、すなわち「トポグラフ」と「ゼ ムレメール」の瞕能を組み合わせてなされるものであろう。上記の ルビアンスキーはゼムレメールであったが、当然計画立案の前提に はトポグラフによる测量の成果があったはずである。また、トポグ ラフが土地分讓以前の街路構成の線を引き、ゼムレメールが事後的 に土地区画の分割線を重ね合わせて引く、ということもあったので はないか。この $2 つ の$ 娥能の具体的組み合わせによっても、市街地 計画は違った形態となる可能性は十分考えられるのである ${ }^{26) 。}$

\section{5-3. 找点形成の政策的背景と市街地計画の基本方針}

以上見てきた中から、1860 年前後におけるロシア極東の初期市 街地計画において計画上の主眼がおかれたのは、市街地区域の範囲 設定、分埕される土地の形態、墓地及び教会の配置、埠頭及び市 場・オープンスペースなどの貿易や交易のための基本的な施設の配 置、という 4 点であったといえる。また、ハバロフスク以外では資 料的な不足があり、具体的な配㯰計画がわかるわけではないが、市 街地計画の計画主体や計画の経緯から考えると、以上の 4 点に加え て軍事施設の配置も等しく重要なものであったと見ることができ る。つまりこれまでの検証から、この初期段階においては、自律的 な機能を包含した都市をそこに計画したわけではなく、端的に言え ば軍事拗点と交易拠点を計画したということを導きうる。

帝政ロシアのシベリアへの東進過程を振り返ると、シベリア地域 が担うべき内政的な役割は、軍事支配拠点の建設と税の取り立てセ ンターの確立であったが、同時にこれを恒久的に機能させるために 重要であったのは、食糧自給方策の確保という生存のための基本要

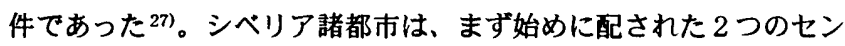
ターを歴史的な核として発展していったが、食糧の移入は多額のコ ストを要したため、続いて都市周辺において農民の移住を促し、食 糧の確保を図ることとなる。

こうした食糧自給方策の確保は、極東での恒久的定着のための重 要な要因であったはずであり、上述した土地区画と区画面積の決定 には、こうした事情も反映していたものと考えられる。少なくとも 初期の段階においては、植民者がある程度は自らの敷地内で自給自 足が可能となるような区画寸法を設定していたことも考えられる。 だが自給のための食糧確保は、この手法のみでは無論不確実であ り、極東においてもシベリアと同様に農民の移住の奖励を政策的に
執りはじめたことが知られる ${ }^{28)}$ 。市街地区画での面積の確保は、食 糧自給のためのあくまでも補完的な手段であったと思われるが、後 に見るようにロシア人の極東への移住政策は、アクセスの悪さが主 要因となり、少なくとも 1880 年代半ばまではしっかりと機能しな かった。結果的に補完的な役割を担ったのは、ロシア領内の都市周 辺に流入した朝鮮人や中国人の農民であった。

こうしたことから極東の初期市街地計画は、完成されるべき都市 の姿を描いたものではなく、本貿的にフロンティア地域における短 期間での軍事败点及び定住地の確保の手だての一つであった。この 植民都市は、ヨーロッパロシアと陸続きで綍いているとはいえ、非 常な遠隔地であり、大々的な建設工事を施すことによる費用対効果 は計算しがたかったに違いない。また：国際条約に基づいていると はいえ、もとの清国領に足を踏み入れた帝政ロシアの極東政策の一 環として生み出されたものであり、とりあえず恒久的な拠点の確保 のための手を打つ必要があったと考えられる。こうした地政学的な 文脈からみても、植民都市の建設は不安定な要因を抱える領土にお いて、拠点の確保をアピールするための最も有効な手段であったは ずである。こうした現実的な制約により、ここで確認したような空 間的条件を基にした計画が生み出されたものと理解される。

\section{謝辞}

本研究は、平成 13 年度大林都市研究振興財団の研究助成により行わ れました。記して感謝の意を表します。

注积

1）帝政ロシア東進過程の概略について、文1）〜3）を参照。

2）図 1は、ロシアの東進過程で筑かれていった肳点の開基年を示している。 Stephanは「ロシア極東 (Dalni Vostok Rossii)」という概念を歴史的に考え る際には、一地方から世界の半分の事柄までを参照せざるを得ない、とし、そ の概念上の伸縮性を指摘している（文 1 p.7)。これは西シベリアから東シベリ ア、カムチャツカ半島、ベーリング海峡を越えたアラスカへ、それに現在の極 東地域、そして19世紀末には中国東北地方までへと拡張していった歴史的過程 を一連のものとして検討する必要性を示している。

3）例えば “Arkhitekturnoe nasledstvo” 誌に揭載されたものを例にとると、 その内容は、市街地パターンの形成の問題から建筑物（初期の木造要塞から教会建 築や20世紀初頭の主に商業者による都市建築まで多岐にわたっている。そこでの 主な対象都市を開基年順に列举すると、チュウメニ (Tiumen' : 1586)、ヤクー ツク (lakutsk : 1632)、ネルチンスク (Nerchinsk : 1654)、イルクーツク (Irkutsk : 1661)、ハバロフスク (1858)、ウラジオストク (1860) などとな る。

4) フラゴペシチェンスクに関しては、文18)、ハバロフスクは、文14)、文 19-20)、ウラジオストクに関しては文 16）と文21-22）を参照。

5）補足的に使用する地図は以下の 2 点。

地図IV : ブラコベシチェンスク

(1)名称・作成年 (所蔵): “Plan' g. Blagoveshensk Amurskoi Oblast"”推 定 1910 年代 (筆者所藏)

(2)樎尺 : 8409 分の 1 (図中の 1 インチが 100 サージェン) 
(3)図中の表記内容: ロット割りとロット番号、それに街区単位でふられてい る通し番号がみられるのが特徵。市街地図のなかでもかなり群しく、街区寸 法も憡ね算定することが可能である。

地図V : ウラジオストク

(1)名称・作成年 (所藏): “Plan" Syshchestvuiushchago 1 Proektirovannago Raspolozheniia Oblastnogo Goroda Vladivostoka Primorskoi Oblasti" 1910 (Library of Far Eastern Study Society 所藏) (2)樎尺 : 10,272 分の 1 (図中の $1 \mathrm{~cm}$ が 50 サージェン)

(3)図中の表記内容: ロット割りとロット番号、それに街区単位でふられてい る通し番号がみられるのが特䈗。市街地図のなかでもかなり詳しく、街区寸 法も概視定することが可能である。

6) ハバロフスクは、1893年までは、ハバロフカと呼ばれた。

7）ファンザは中国人の小屋を指す。石造または、草入りのレンガ造り。

8) 彼はウラジオストク最初の民間人居住者であり、後の地主層の一人となる。 文22）写真 57 及び 61 のキャブション

9）文 14）p122、文16）p86、及び文22）pp.50-51

10) 文 14) p.122

11) 文 22) p27

12) 文 22) $\mathrm{p} 32$ 。

13) 文 22) pp.50-51

14) 文 16) $\mathrm{p} 86$

15）文18）本文 3 ページ目。同書にはノンフル無し。

16）1860年代におけるウラジオストクは、治海州南部諸港の一つにすぎず、ポ シェットと競合関係にあり、優位性が高かったわけではない。拠点として新た な位㯰づけを猪得するのは、ニコラエフスクより治海州軍務知事の本拋が移䎐 する 1872 年以降である。またハバロフスクも1880年に沿海州行政の中心が移 転した後、1884 年にさらにアムール地方の行政的中心地となり、重要性が高 まったが、その時点においても人口は 5,000 人に過ぎなかった。ブラゴベシチェ ンスク俊位の傾向は19世紀の間を通じてみられ、1900年の時点でフララゴベシ チェンスクの人口は 50,000 人を数え、この数はハバロフスク、ウラジオストク の人口を足した繁よりも多いものであった。文1）p83を参照。

17) 文 12) を参照。

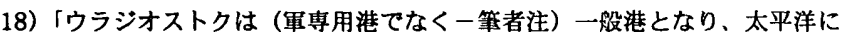
面する都市とせねばならないことに留意する必要がある。そこで、以下の諸点 を命ずる。

i）土地は瞵入を望むもの全てに提供されなくてはならないこと、ii）それぞ れのロットは15から30サージェン四方の大きさで1つの街区は 8 つのロット から構成されること、iii）街区は方形をしていること。」文 15) p.5

19）1897 年ハバロフスクーウラジオストク間鉄道開通。プラゴベシチェンス クの鉄道開通は1913 年。

20）「道路の蝠員は最低 20 サージェン必要である。」文22）p32。

21）ウラジオストク・アルセーニエフ博物館での聞き取り（1999 年 7 月）及 ひ、ハバロフスク歴史资料館でのヒアリング (1999 年 8 月)。双方で同様の内 容の情報を得たが、参照すべき文献は未見である。

22ここれは同じく帝政ロシアによって計画された 1900 年前後のハルビンの例 と比较すれば明隐になる。ハルビンの旧キタイスカヤ通り(現中央大街) 沿道 における土地ロットの分割は、基本的には10サージェン四方、すなわち 100 平方サージェンが基本とされており、また一部では沿道部分の敷地間口が、9 サージェンであることが確認される。このサイズは、本稤での封嗮 3 都市にお けるいかなるロットよりも小さいも。このサイズを定めると同時に建築を促進 するような手段もとっており、都市的建築を誘導するという意図が含まれてい たと考えられる。

23）もちろん、一ロにグリッドパターンといってもそのバリエーションはさま ざまであるが、一般に、(1)土地分割の容易性、(2)合理的な交通システムの確保、 (3)住民平等の理念の体現、といった理由からもたらされたといわれる。特にグ リッドパターンを広く世界に広めたスペインによる植民都市の計画と建設上の 墸条件は、イインド法典」によって定められたとされる。(レオナルド・ベネー ヴォ口（佐野敬彦・林寛治訳）「図説都市の世界史 3 近世」相模書房, 1983 pp109-158、アーヴィン・Y・ガランタイ (堀池秀人訳)「都市はどのように つくられてきたか」井上書院,1983 pp.29-47)。

24) フララコベシチェンスク、ニコラエフスクのプランの、特に正方形に近い街 区形状は、困像的に見ると、スペインによる中南米の俱民都市のパターンとの 類縁性を想起させる。

25)「トポグラフ (Topograf)」と「ゼムレメール (Zemlemer)」については 以下を参照。(出所 : “Entsiklopedicheskii slovar”" (Reprintnoe vosproizvedenie izd. F.A. Brokgauz-I.A.Efron, 1890 g.) ,Moscow,Terra, 1990-1994.)

26）同様の南下政策の中でロシア帝国はハルビンやタルニー（大連）におい ては俊れたアーバンデザインを残しているが、極東の 3 都市においては、少な くとも初期の段階においてそうした手法の活用は見られない。その差異を最も 明確に表しているのは、ハルビンや大連の計画においては、市街地計画の段階 から建筑家が関与していることてあるるこのような計画に管わる具体的な倳能 の組み合わせの连いには、極東 3 都市との間の初期市街地計画における本質的 な違いが現れているとみることができる。文4）pp.39-48、文7） pp.23-30 27）文 3) 参照

28）早い時期では 1861 年 3 月に政府は、東部地方への移民に関する法令（通 称「ムラウィヨフ移民法」）を公布したことが知られる。土地供与、徽兵免除、 納税免除により移民を哭励し、その後の 10 年間で、5,000人に及ぶ人々が、西 シベリア、ザバイカル、ウォルカ、そしてウラル地方からプリアムール地方へ 移動し、この地方の富裕な農民層の中核を形成した。しかし、ロシア人移民は 徐々にしか増加せず、治海州のウスリ一地方に関しては、1860～70 年には 4,444 人の移民が到着したが、つづく 12 年間（1871～82 年）にはわずかに 742 人しか来なかった、という数字が紹介されている。和田春謿「ロシア领極 東の朝鲜人」(所収：『社会科学研究』Vol.40-6,1989) p.238

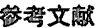

文 1) Stephan, John J. "The Russian Far East: a History" ,Stanford University Press,Stanford, 1994

文 2 ) Kotkin, S.,Wolff, D.(ed) "Rediscovering Russia in Asia",M.E.Sharp, New York, 1996

文 3 ) ジェームス・フォーシス（森本和男訳）「シベリア先住民の歷史 : ロシア の北方アジア植民地」晚流社 , 1998

文 4) 越沢明「哈爾浜の都市計画 1898-1945」, 総和社,1989

文5）「大連の都市計画史（1898～1945 年)」,1984，(所収：『日中経済協会 報』134 136号, 1984)

文6）西澤泰彦「『満洲』都市物語 ハルビン・大連・瀋陽・長春」，河出書房 新社,1996

文 7) 西澤泰彦「図説大連都市物語」，河出書房新社,1999

文8）原暉之「ウラジオストク物語」三省堂,1998

文9）佐藤洋一・跣見和重・戸沼幸市「旧セミョーノフスキーバザール周辺に おける街区形態の形成 ウラジオストク中心市街地の都市空間形成に関する研 究 その $1 」, 1998$, (所収: 『日本建築学会計画系論文集』No.505,1998) 文10）佐藤洋一・戸沼幸市「スヴィランスカヤ通り沿道に現存する建築物 ウラジオストク中心市街地の都市空間形成に関する研究その 2 」,1999, (所収: 阳本建策学会計画系論文集』No.522,1999)

文11) Proskuriakova, T.S. "Planirovochnye kompozitsii gorodovkrepostei sibiri(vtoroi poloviny XVII - 60-e gg. XVIII v." (所収 : "Arkhitekturnoe nasledstvo" No.25(1972))

文 12) Proskuriakova, T.S. "Staroe I Novoe v Gradostroitel'stve Sibiri (vtoraia polpvona XVII-XVIII vV.)" (所収 : “Arkhitekturnoe nasledstvo" No.31(1978))

文13) Kradin, N.P. "Pamiatniki Arkhitektury Khabarovska", Izdatel'stvo Etnos-DV,Khabarovsk,1996

文 14) Kradin, N.P. “Khabarovska Istoricheskii” ,1998, (所収 : “Dal'nii Vostok" 1998.5-6.)

文15) Riabov, N., Obertas,V., "Istorii zastoroiki Vladivostoka" ,Primorskoe knizhoe izdatel'stvo,Vladivostok, 1961

文16) Obertas,V.A. "Formirovanie planirovochnoi sturuktury Vladivostoka $v X X X V$ ”, 1976 (所収 : “Arkhitekturnoe nasledstvo" No.25 (1976),pp.85-94)

文17) Obertas,V.A. “Arkhitektura Starogo Vladivostoka”,1980, (所収 : "Arkhitekturnoe nasledstvo" No.28(1980),pp.107-118)

文 18) "Blagoveshchensk -fotorasskaz" Gosudarstvennoe proizvodstvenno-kommercheskoe izdatel'stvo Zeia,Blagoveshchensk,199 文 19) "Khabarovskii krai" ,Izdatel'stvo Utro Rossii, Vladivostok, 1996 文 20) "Khabarovsk : geograficheskii atlas" Glavnoe upravlenie geodezi i kartografii, Moskva 1988

文 21) Krushanov, A.I. "Nekotorye voprosy sotsial'no-ekonomicheskoi storii Vladivostoka(1860-1916)” (所収: “Materialy po istorii Vladivostok, Kn. 1-2" Primorskoe knizhoe izdatel'stvo, Vladivostok, 1960)

文 22) Matveev,N.P. "Kratkii istoricheskii ocherk g. Vladivostoka" izdatel'stvo Ussuri, Vladivostok,1990 (再版)

文22) “Strii Vladivostok" Utro Rossii, Vladivostok, 1992

（2002年 9 月 10 日原稿受理，2003年 1 月 29 日採用決定） 